\title{
Nemszteroid gyulladáscsökkentő szerek a mozgásszervi fájdalom csillapításában
}

\author{
Sütő Gábor dr. \\ Pécsi Tudományegyetem, Orvostudományi Kar, II. Belgyógyászati Klinika és Nephrológiai Centrum, Pécs
}

\begin{abstract}
A reumatológiai kórképekben a hatásos fájdalomcsillapítás a mai napig kihívás. A gyulladásos reumatológiai betegségekben a leghatásosabb fájdalomcsillapítás az alapbetegség kezelése. Adjuváns kezelésként analgetikumot, nemszteroid gyulladáscsökkentőt és opioid szert adhatunk. A degeneratív kórképekben a hatásos fájdalomcsillapítás áll a terápia középpontjában. A mai napig a nemszteroid gyulladáscsökkentő szerek a leghatásosabb fájdalomcsillapítók. A gyógyszerek biztonságosságát illetően nagyon sok kérdés merült fel. Nincsen olyan szerv, amely ne lenne érintett, de a legsúlyosabb szövődménynek a gyomor-bél rendszer megbetegedését tartottuk. A XXI. század elején a cardiovascularis események felismerése jelentősen megváltoztatta a gondolkodásunkat ezekrôl a gyógyszerekről a fájdalomcsillapítás keretében.
\end{abstract}

Orv Hetil. 2019; 160(22): 855-860.

Kulcsszavak: arthritis, arthrosis, fájdalom, fájdalomcsillapítás, nemszteroid gyulladáscsökkentő szerek

\section{Non-steroidal anti-inflammatory drugs for relieving pain in musculoskeletal disorders}

Pain control in musculoskeletal disorders is still a challenging task. The most effective treatment of pain in autoimmune and immune-mediated diseases is the treatment of the disease itself. Analgesics, non-steroidal anti-inflammatory drugs and opioids are used to relieve pain. Analgesia is the central intervention of degenerative disorders. The most effective analgesic compounds are the non-steroidal anti-inflammatory drugs (NSAIDs). Concerns are raised regarding the safety of NSAIDs. There is not any organ which is not involved in adverse reactions, but the damage of the gastrointestinal system has been considered the most serious one for a long time. In the 21 st century, the recognition of cardiovascular complications led to the re-evaluation of the role of these drugs in analgesia.

Keywords: arthritis, arthrosis, pain, analgesia, non-steroidal anti-inflammatory drugs

Sütő G. [Non-steroidal anti-inflammatory drugs for relieving pain in musculoskeletal disorders]. Orv Hetil. 2019; 160(22): 855-860.

(Beérkezett: 2019. február 10., elfogadva: 2019. február 24.)

\section{Rövidítések}

ACR $=($ American College of Rheumatology) Amerikai Reumatológiai Kollégium; CHMP $=($ Committee for Medicinal Products for Human Use) Emberi Felhasználásra Szánt Gyógyszerkészítmények Bizottsága; COX = ciklooxigenáz; EMA = (European Medicines Agency) Európai Gyógyszerészeti Ügynökség; EULAR = (European League Against Rheumatism) Európai Reumatológiai Társaság; NICE = (National Institute for Health and Care Excellence) Az Egészség és Klinikai Kiválóság Nemzeti Intézete; NNT = (number needed to treat) a kezelni szükséges betegek száma; NSAIDs = (non-steroidal anti-inflammatory drugs) nemszteroid gyulladáscsökkentő szerek; OARSI $=($ Osteoarthritis Research Society International $)$
Nemzetközi Osteoarthritis Kutatási Társaság; PPI = (protonpump inhibitor) protonpumpagátló; $\mathrm{WHO}=($ Word Health Organization) Egészségügyi Világszervezet

A mozgásszervi fájdalmak az orvos-beteg találkozások leggyakoribb okai közé tartoznak. Jelentős részüket a gyulladásos kórképek teszik ki. Az inflammatoricus folyamatok szerepe egyértelmü az autoimmun és immunmediált ízületi betegségek kialakulásában, de az is egyre világosabb, hogy a degeneratív ízületi betegségek kialakulásában is jelentősek a gyulladásos folyamatok, ame- 
lyek a porc-csont-csontvelő kommunikáció következményeként alakulnak ki [1].

A fájdalomcsillapítás az egyik legalapvetőbb igény a betegek részéról. A terápiával szembeni elégedettség egyik legjelentősebb mérôszáma, hogy a betegek mozgásszervi fájdalma milyen mértékben enyhül [2]. Nagyon sokféle fájdalomcsillapítási módszer áll rendelkezésre, amelyek helye a terápiás protokollokban sokat változott az elmúlt évtizedekben.

\section{A fájdalomérzet és a fájdalomcsillapítás}

A fájdalomérzet kialakulása nagyon összetett folyamat. A patofizológiai folyamatok nagy részét jól ismerjük, tudjuk, hogy a szöveti károsodás, a gyulladás milyen anatómiai struktúrákon keresztül, milyen jelátvivők révén alakítja ki a fájdalomérzetet. Ezt a folyamatot azonban rengeteg tényező befolyásolja: genetikai háttér, környezeti faktorok, kulturális örökség, hangulat, stressz, kifáradás [3]. Különösen a 3 hónapon túl fennálló, krónikus fájdalom menedzselése jelent emiatt jelentős problémát.

Mindezek következtében a fájdalomcsillapítás mindegyik kórképben nagyon összetett feladat, többféle lehetőséget kell integrálni holisztikus megközelítési móddal. A mozgásszervi betegségekben az eltérő patológiai folyamatok miatt a legtöbb terápiás ajánlás betegségspecifikus. Ezek nemcsak a gyulladásos vagy degeneratív betegségek között tesznek különbséget, hanem az egyes betegségekre adnak individuális javaslatot. A térdarthrosis kezelésére vonatkozó ajánlások például nem alkalmazhatók a csípőarthrosis kezelésére. Ennek következtében személyre szabott kezelési protokollt kell kialakítani, amelynek során megfelelő ütemezéssel és arányban kell az egyes kezelési lépcsőket felépíteni. A betegek edukációja, hogy saját maguk miként tudják a lehetố leghatékonyabban vezetni a fájdalomcsillapítást, elengedhetetlen. A mozgásterápia, a testsúlycsökkentés, a dohányzás felfüggesztése, a munka és az otthoni tevékenység áttekintése az első lépés, elsősorban a degeneratív eredetú fájdalomban [4]. A termoterápia, az elektromos kezelések, a manuálterápia, a különböző segédeszközök és ortézisek hasznos kiegészító lehetôségei a fájdalomcsillapításnak. A gyulladásos fájdalom kezelésében is fontosak ezek a tényezők, de a fájdalom biológiai természeténél fogva itt a gyulladáscsökkentő gyógyszeres kezeléshez hamarabb kell nyúlni.

A musculoskeletalis fájdalomcsillapításban is a WHOnak a daganatos betegségekben alkalmazott 'fájdalomlétra' [5] sémája az alap szinte minden ajánlásban. A betegségek jellegéből fakadóan azonban vannak olyan terápiás lehetőségek, amelyek hangsúlyozottabban szerepelnek a reumatológiai fájdalom csillapításában. A lokális fájdalomcsillapítás az egyik ilyen lehetőség, amelyet jól ki lehet használni a hatásos fájdalomcsillapítás elérésében úgy, hogy a szisztémás adagolásból fakadó mellékhatásokat el tudjuk kerülni [6].
A fájdalomcsillapítás legelső lépcsőjét szinte minden esetben az analgetikumok alkalmazása jelenti. A paracetamol (az angolszász irodalomban fenacetin) előnye, hogy kevés gastrointestinalis és vascularis mellékhatása van. Ugyanakkor a fájdalomcsillapító hatás a nemszteroid gyulladáscsökkentőkkel összehasonlítva jóval szerényebb, a betegek kevésbé preferálják [7], mivel analgetikus hatású, így gyulladást nem csökkent. Emellett a terápiás tartomány szúk, napi $4 \mathrm{~g}$ felett már megjelenhet a hepatotoxicitás, amit könnyú elérni, fő́leg, ha a betegek többféle paracetamoltartalmú hatóanyagot kombinálnak.

A fájdalomcsillapítás nagy csoportját az opioid fájdalomcsillapítók képezik. Gyulladásgátló hatásuk nincs, így gyulladásos kórképekben inkább kiegészító szerepük van. A degeneratív kórképeket kísérő mozgásszervi fájdalomban kevésbé hatásosak. A tramadol paracetamollal kombinálva hatásosabb készítmény [8]. Alkalmazásukat korlátozza [8], hogy a tramadol - elsősorban 65 év felett, nőknél - szédülést, járásbizonytalanságot, hányingert, gyengeséget okozhat, ezért adásával óvatosnak kell lenni. Segít a mellékhatás-kivédésben, ha a gyógyszer szedését a beteg este kezdi, majd néhány naponta emeli az adagot a szükséges mennyiségig.

\section{A nemszteroid gyulladáscsökkentő szerek azonosságai és különbözőségei}

A nemszteroid gyulladáscsökkentő szerek a legelterjedtebb gyulladás- és fájdalomcsillapító gyógyszerek. Nemcsak a mozgásszervi fájdalmak kezelésére, hanem fejfájás, menstruációs fájdalmak kezelésére, lázcsillapításra is alkalmazzuk óket. John Vane 1971-ben írta le, hogy az aszpirin a prosztaglandinszintézis gátlásán keresztül fejti ki hatását [9]. Sokáig azt gondoltuk, hogy a különböző gyulladásgátló-fájdalomcsillapító gyógyszerek egyforma hatásossággal csökkentik a fájdalmat. Az biztos, hogy nagyságrendi eltérések a hatásosságban nincsenek, de az egyes gyógyszerek között azért vannak mérhető különbségek. A fájdalom mérése azonban nem egyszerü, a kapott eredmény függ a módszertől, valamint a gyógyszerek hatásosságát számos tényező befolyásolja: a fájdalom eredete, fennállása, a beteg neme, kora, alap- és társbetegségei, a gyógyszer alkalmazási módja, adagja. Az Oxford Fájdalomcsoport alkotott egy táblázatot (1. táblá$z a t$ ), amelyben az akut fájdalom legalább $50 \%$-os csökkenését mérték 4-6 órás kezelés után [10]. Összesen 47 különböző terápiás lehetőséget vizsgáltak. Az eredményt a kezelni szükséges betegek számában (number needed to treat $=\mathrm{NNT}$ ) fejezték ki, amely azt jelenti, hogy a placebocsoporthoz képest még hány beteget kell kezelni, hogy a fájdalom legalább egynél több mint a felére csökkenjen. A táblázat érdekessége, hogy az első nyolc helyen csak nemszteroid gyulladáscsökkentők állnak, ettől hátrafelé jelennek meg az analgetikumok és az opioid fájdalomcsillapítók, valamint a kombinációs készítmények. Az első helyen a már nem elérhető valdeco- 
A leggyakrabban alkalmazott nemszteroid gyulladáscsökkentô szerek hatáserőssége a morfinnal és a paracetamollal összevetve a NNT alapján (a [10] referencia adatainak alapján)

\begin{tabular}{llll}
\hline NNT & $\begin{array}{l}\text { A vizsgált terápiás } \\
\text { lehetőségek száma } \\
(\text { összesen } 47)\end{array}$ & Nemszteroid gyulladáscsökkentő & NNT \\
\hline$<2$ & 7 & $\begin{array}{l}\text { Ibuprofén } 800 \mathrm{mg} \\
\text { Diklofenák 100 mg }\end{array}$ & 1,6 \\
& & Naproxén $440 \mathrm{mg}$ & 1,9 \\
\hline $2,1-3$ & 23 & Aszpirin 1200 mg & 2,3 \\
& & Morfin 10 mg i.m. & 2,4 \\
& & & 2,9 \\
\hline $3,1-4$ & 6 & Paracetamol $500 \mathrm{mg}$ & 3,5 \\
\hline $4,1-5$ & 5 & Paracetamol 1000 mg & 3,7 \\
& & Paracetamol 1500 mg & 3,8 \\
& & Tramadol 100 mg & 4,8 \\
\hline$>5$ & 6 & Tramadol 50 mg & 8,3 \\
\hline
\end{tabular}

NNT = a kezelni szükséges betegek száma

2. táblázat |A nemszteroid gyulladáscsökkentő szerek leggyakoribb mellékhatásai

Gyomor-bél rendszer Oesophagusgyulladás, fekély, strictura Gastroduodenalis erosio, fekély Vékonybélfekély, boholyatrophia, strictura Gyulladásos bélbetegségek aktiválódása Vastagbélgyulladás, fekély, vérzés, perforáció Intestinalis diverticulumok komplikációi

Cardiovascularis rendszer Myocardialis infarctus Fatális myocardialis infarctus Hirtelen szívhalál Stroke

\begin{tabular}{ll}
\hline Máj- és epeutak & Akut hepatocellularis laesio \\
& $\begin{array}{l}\text { Krónikus granulomatosus hepatitis } \\
\text { Krónikus aktív hepatitis } \\
\text { Intrahepaticus cholestasis }\end{array}$ \\
\hline Vese & Só- és vízretenció \\
& Akut reverzibilis veseelégtelenség \\
& Nephrosisszindróma \\
& Interstitialis nephritis \\
& Vesepapilla-necrosis \\
\hline Csontvelő & Agranulocytosis \\
& Aplasticus anaemia \\
\hline Tüdő & Asztmás rohamot provokálhatnak \\
\hline Bőr & Rash \\
& Pruritus \\
& Urticaria (aszpirin) \\
& Fotoszenzitivitás (piroxikám) \\
\hline Központi idegrendszer & Fülzúgás, halláscsökkenés (szalicilátok) \\
& Fejfájás, szédülés, aluszékonyság \\
& Depresszió (indometacin) \\
& Asepticus meningitis \\
\hline
\end{tabular}

xib áll, a következő helyen a forgalomban lévő ibuprofén 800 mg adagja található, 1,6 NNT-vel. Ez a gyakorlatban azt jelenti, hogy két kezelt beteg közül legalább egy tapasztal jelentős analgesiát. A gyakran alkalmazott dik-

\section{Elsősorban COX1-gátlás}

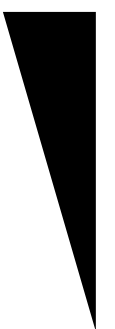

Flurbiprofen

Ketoprofen

Aszpirin

Naproxén

Indometacin

Ibuprofén

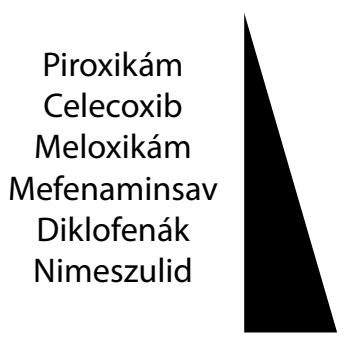

Elsősorban COX2-gátlás

1. ábra

$$
\mid \begin{aligned}
& \text { A nemszteroid gyulladáscsökkentő szerek eróssége a COX1- } \\
& \text { vagy COX2-gátlás szerint } \\
& \text { COX = ciklooxigenáz }
\end{aligned}
$$

lofenák 100 mg-os adagja $(\mathrm{NNT}=1,9)$ a hatodik helyen áll. A morfin ezekhez a gyógyszerekhez képest rosszabbul teljesít $(\mathrm{NNT}=2,9)$, az analgetikum paracetamol még kevésbé hatásos $(\mathrm{NNT}=3,5-3,8)$.

\section{A gastrointestinalis és cardiovascularis szövődmények}

A prosztaglandinszintézis gátlásának felismerése óta eltelt 47 év során nagyon sokat tanultunk ezekról a gyógyszerekről, múködésükről, nem kívánt hatásaikról [11] (2. táblázat). A figyelem középpontjában sokáig a gastrointestinalis mellékhatások voltak, mivel jelentős morbiditással, hospitalizációval és mortalitással is jártak [12]. A nemszteroid gyulladáscsökkentő szerek erosiv gastritist, fekélybetegséget, gastrointestinalis vérzést, perforációt, obstrukciót, stricturákat, következményes anaemiát és hypalbuminaemiát okoznak. Jelentős mérföldkő volt a ciklooxigenáz enzim különböző izotípusainak felfedezése. Ez a felismerés adott löketet azoknak a vizsgálatoknak, amelyekben az egyes gyógyszerek COXI/COX2 gátlásának mértékét vizsgálták (1. ábra). A jól ismert gastrointestinalis mellékhatásokat úgy kívántuk kivédeni, hogy egyrészt a gyulladáscsökkentők alkalmazása során figyelembe kellett venni a rizikót (3. táblázat), másrészt megindult az elsősorban a COX2 enzimet gátló gyógyszerek fejlesztése. Emellett a közelmúlt nagy áttekintő analízisei már megmutatták, hogy a vascularis és a gastrointestinalis mellékhatások kisebb-nagyobb mértékben minden gyógyszerre jellemzők, illetve a kétféle nem kívánt esemény elófordulása elsősorban a $\mathrm{COXl} / \mathrm{COX} 2$ gátlás arányával függ össze [12]. 
A nemszteroid gyulladáscsökkentôk gastrointestinalis mellékhatásainak rizikófaktorai

- Fekélybetegség az anamnézisben

- 60 év feletti életkor

- Női nem

- Magas dózis

- Tartós alkalmazás

- Kombinált NSAID-szalicilát kezelés

- Társbetegségek:

o szív-, tüdő-, vesebetegség

o májkárosodás

- Kortikoszteroid adása

- Antikoaguláns adása

- Helicobacter pylori-pozitivitás

- Alkohol

- Dohányzás

- Kávéfogyasztás

NSAID = nemszteroid gyulladáscsökkentő

Ennek kapcsán került a figyelem középpontjába a szívés érrendszeri mellékhatások problémája. 2004-ben a rofecoxib klinikai vizsgálati eredményeinek áttekintése során merült fel az első kétely a gyógyszer biztonságosságával kapcsolatban [13]. Korábban azért nem derült ki az érrendszert érintő szövődmények előfordulása, mert egyrészt hiányoztak a hosszú távú, több évet átfogó vizsgálatok, másrészt a mellékhatások gyakorisága nem egyforma. A gastrointestinalis szövődmények rizikója 3-4-szeres, a cardiovascularis 1,3-1,4-szeres tartományban van, így ez utóbbiakra nehezebben derült fény. Az eredmények miatt a gyártó a gyógyszert a forgalomból kivonta, de a celecoxib alkalmazásával felmerült hasonló thrombemboliás rizikófokozódás miatt a COX2-gátlók mint gyógyszercsoport oki szerepe merült fel ezekben a szövődményekben. A kezdeti megfigyelések a túlzott COX2-szelektivitásnak tulajdonították a súlyos, akár fatális cardiovascularis szövődmények megjelenését, de a vizsgálatot kiterjesztették a nemszelektív nemszteroid gyógyszerekre. 2006-ban már látható volt, hogy a nemszteroid gyulladáscsökkentőkre mint hatástani csoportra a thromboticus komplikációk jellemzők lehetnek, fóleg ha nagyobb adagok tartós szedése áll fenn. Az EMA állásfoglalása a nemszteroid gyulladáscsökkentő szerek cardiovascularis kockázatára vonatkozóan 2012ben született meg [14]. Elvégezték a klinikai vizsgálatok, az obszervációs vizsgálatok és az individuális epidemiológiai vizsgálatok metaanalízisét. A három leggyakrabban alkalmazott gyulladáscsökkentő szer a diklofenák, az ibuprofén és a naproxen volt, így ezekre vonatkozott a legtöbb megfigyelés.

Ebben a véleményben a legkisebb thromboticus rizikót a naproxén alkalmazása jelentette. Ennek valószínúleg az az oka, hogy a gyógyszer gátolni képes a thrombocytaaggregatiót. Az ibuprofén esetében is sok adat áll rendelkezésre, amelyek biztosítják a gyógyszer helyét a fájdalomcsillapításban. Az etoricoxibbal és a diklofenákkal összehasonlítva jobb a thromboticus rizikóprofil, de a naproxénhez képes több thrombemboliás szövődményt regisztráltak. Ez a különbség a legtöbb vizsgálatban 10\%-on belül volt [15], és már ekkor felmerült, hogy az alacsonyabb ibuprofénadag esetén a gyógyszer alkalmazása biztonságos. Ezt a gondolatot erősítette meg az EMA 2015-ös állásfoglalása, amely szerint az ibuprofén napi $1200 \mathrm{mg}$ dózisig nem fokozza a cardiovascularis rizikót [16]. Nagyobb adagnak a napi 2400 mg-ot tekintik az ibuprofén esetében. A jelentés külön hangsúlyozza, hogy az ibuprofénre vonatkozó ajánlás alkalmazható a dexibuprofénre is, amelynek esetében nagy adagnak a napi $1200 \mathrm{mg}$ feletti mennyiség számít.

A diklofenák esetében a már rendelkezésre álló adatokat erősítették meg [16]: a cardiovascularis rizikó nagyobb, mint a nemszelektív nemszteroid gyulladáscsökkentők esetében, és nagyságrendjében a coxibokhoz hasonló. A rizikó dózisfüggő, és a $75 \mathrm{mg} /$ nap mennyiség felett emelkedik.

A többi nemszteroid gyulladáscsökkentő esetében az adatok nem elegendőek konklúzió levonásához, de a CHMP úgy gondolja, hogy a cardiovascularis rizikó fokozódása mint a nemszteroid gyulladáscsökkentők osztályára jellemző mellékhatás továbbra sem vethető el $[15,16]$.

4. táblázat | Ajánlások a nemszteroid gyulladáscsökkentők alkalmazására

- NSAID megfelelő ideig tartó adása

- Topikális szer az első, ha ez lehetséges: krémek, tapaszok

- Nem farmakológiai fájdalomcsillapítás

- Gastroprotectiv szer együtt adása: PPI, H2-blokkolók

- Rizikófaktorok esetén mindig gastroprotectiv szer együtt adása: PPI

- Magas gastrointestinalis kockázatú betegeknél:

- $\quad$ COX2 szelektív készítménye alkalmazható, figyelembe véve:

- a cardiovascularis rizikót,

- az adagot,

- $\quad$ a kezelés időtartamát

- Elővigyázatos alkalmazás gyakori monitorozással:

koszorúér-betegség,

cerebrovascularis betegség,

hypertonia,

vesebetegség,

congestiv szívelégtelenség

- Aszpirin vagy szteroid együtt adása:

a gastropathia előfordulását fokozza,

nemszelektív NSAID vagy COX2-gátló adása mellett a hatása kérdéses

COX = ciklooxigenáz; NSAID = nemszteroid gyulladáscsökkentő; PPI = protonpumpagátló 


\section{A nemszteroid gyulladáscsökkentő szerek a gyakorlatban}

A mozgásszervi fájdalom gyógyszeres csillapításának kezelésére a leghatásosabb, ugyanakkor a legbiztonságosabb nemszteroid gyulladáscsökkentő gyógyszer kiválasztása a feladat. A hatásosság megítélése nem egyszerú. A fájdalomcsillapítás sikerességét meghatározza maga a betegség, az egyes kórképekben nyert tapasztalatok nem feltétlenül extrapolálhatók más betegségre. Amellett, hogy gyulladásos vagy degeneratív eredetű a fájdalom, kis vagy nagy ízület érintett, korai vagy előrehaladott betegségről van szó, a sikerességet befolyásolja a beteg kora, neme, a társbetegségek, az egyéb gyógyszerelés (4. táblázat). Az ajánlások gyakrabban egy-egy kórképre vonatkoznak, az átfogó, minden esetben alkalmazható ajánlások ritkábbak.

Az EULAR [17] a gyulladásos és degeneratív jellegú ízületek fájdalomcsillapítását illetően egységes ajánlást készített 2018-ban. A betegség felmérése és a kezelés megtervezése során betegcentrikus megközelítést kell alkalmazni, amelyben az egészségügyi szakemberek felelőssége különleges: 1) ismerniük kell a fájdalomérzet kialakulásának komplex folyamatát, 2) tudni kell az arthritisek és az arthrosis kialakulásának patológiáját, kezelését és szövődményeit, 3 ) meg kell tudni különböztetni a helyi és a generalizált fájdalmat, amelyek gyakran együtt jelentkeznek. A betegeknek személyre szabott kezelési tervet kell kapniuk, amelynek szükség szerint része az edukáció, a mozgás, a segédeszközök biztosítása, a pszichológiai és szociális segítség, az alvás befolyásolása, a testsúlykontroll, a gyógyszeres kezelés, a multidiszciplináris megközelítés. Ez az ajánlás nagyon hűen tükrözi a fájdalom kialakulásának összetettségét, és a kezelésben nemcsak a farmakológiai terápiára teszi a hangsúlyt, ha-

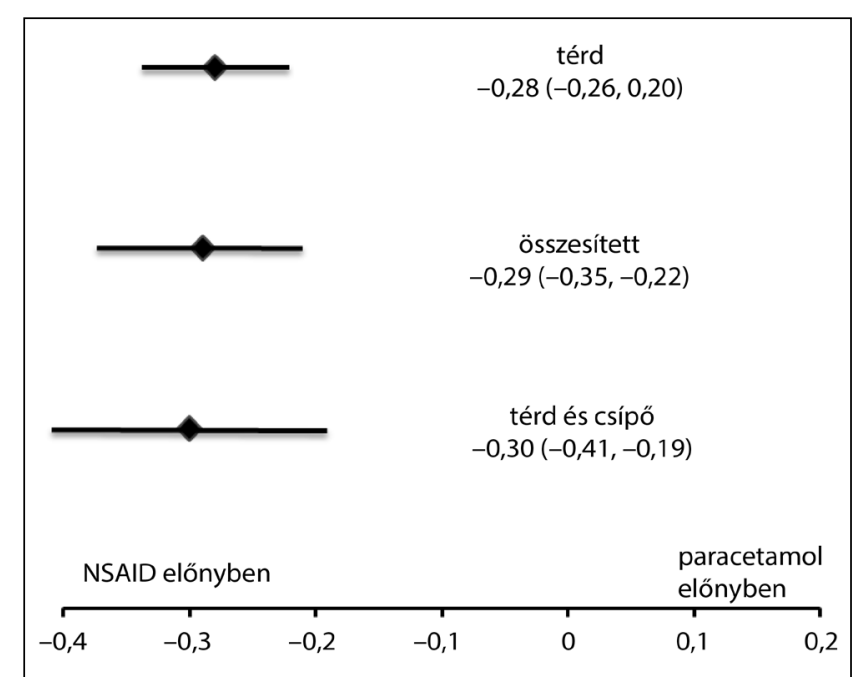

2. ábra

A nemszteroid gyulladáscsökkentők és a paracetamol összehasonlítása (az átlagok standarizált különbsége, 95\% konfidenciaintervallum) csípó- és térdosteoarthritis kezelésében (a [7] referencia alapján módosítva)

NSAID = nemszteroid gyulladáscsökkentő nem az egy holisztikus megközelítési mód egyik alkotórésze.

Az ACR 2012-es állásfoglalása [18] a csukló-, a csípőés a térdarthrosis kezelését tárgyalja. A farmakológiai intervenciók között a csukló és a térd esetében javasolja topikális nemszteroid gyulladáscsökkentők alkalmazását. Per os nemszteroid gyulladáscsökkentők szedését mindhárom kórképben ajánlja.

A térdosteoarthritis nem sebészi kezelésének OARSIajánlása [19] minden esetben javasolja nemszteroid gyulladáscsökkentő alkalmazását. Egy ízület megbetegedése esetén előtérbe helyezi a topikális nemszteroid kezelést, fóleg, ha a betegnél egyéb komorbiditások is jelen vannak. Több ízület esetén a per os kezelést, komorbiditások esetén nemszelektív vagy szelektív szerrel, komorbiditások esetén szelektív nemszteroidokat ajánl. Ennek az ajánlásnak hátránya, hogy a különböző komorbiditásokat együtt tárgyalja, nem tesz különbséget közöttük. Azonban akkor járunk el helyesen, ha a gyakorlatban a gastrointestinalis vagy a carediovascularis rizikófaktorok jelenléte alapján választunk a szelektív és a nemszelektív nemszteroid gyulladásgátlók között.

A NICE osteoarthritiskezelési ajánlását 2019-ben frissítették [4]. A holisztikus megközelítésen belül a gyógyszeres kezelést részletesen tárgyalja. A csukló- és a térdarthrosis kezelésében javasolja a topikális nemszteroid gyulladáscsökkentő gyógyszerek alkalmazását. Ha ez a kezelés vagy a paracetamol hatástalan, a nemszteroid gyulladáscsökkentők/COX2-gátlók adását a lehető legkisebb adagban, a legrövidebb ideig javasolja alkalmazni. Az első választás lehet hagyományos NSAID vagy egy COX2-gátló (de nem 60 mg etoricoxib). Mindegyik esetben PPI-kezelés is szükséges. A gyógyszerkiválasztásnál felhívja a figyelmet a rizikófaktoroknak és a beteg életkorának a figyelembevételére. Aszpirint szedő betegnél pedig meg kell fontolni egyéb gyógyszeres kezelési lehetőséget a nemszteroid gyulladáscsökkentő kezelés bevezetése előtt.

A mozgásszervi fájdalom gyógyszeres enyhítésében, akár gyulladásos, akár degeneratív eredetű, a nemszteroid gyulladáscsökkentők manapság is gyakorlatilag az első helyen állnak. Hatékonyságban [10] és betegpreferenciában (2. ábra) is felülmúlják az analgetikumokat és az opioid gyógyszereket. Azonban a nem kívánt események széles spektrumát mutatják, amelyeket megfelelő rizikóanalízissel ritkítani vagy enyhíteni lehet. Első lépésben a gyógyszer alkalmazási útját kell eldönteni. Egy-egy régió lokális fájdalomcsillapítása topikális készítménnyel is sikeres lehet, így a szisztémás mellékhatások előfordulását lehet megelőzni. Per os alkalmazás esetén elsősorban a gastrointestinalis és a cardiovascularis tényezóket és a társgyógyszereket (szalicilátok, véralvadásgátlók) kell áttekinteni, de gondolni kell egyéb szervi hatásokra is, úgymint a vesemúködés beszúlkülése, hypertonia kialakulása. Ha jól alkalmazzuk ismereteinket, akkor a toxicitás rizikóját minimalizálni, a hatásosságot pedig maximalizálni tudjuk. 
Anyagi támogatás: A közlemény megírása anyagi támogatásban nem részesült.

A szerző a cikk végleges változatát elolvasta és jóváhagyta.

Érdekeltségek: A szerzőnek nincsenek érdekeltségei.

\section{Irodalom}

[1] Pelletier JP. The influence of tissue cross-talking on OA progression: role of nonsteroidal antiinflammatory drugs. Osteoarthritis Cartilage 1999; 7: 374-376.

[2] Cunha-Miranda L, Costa L, Ribeiro JS. NEAR study: Needs and Expectations in Rheumatoid ARthritis - do we know our patients needs? Acta Reumatol Port. 2010; 35: 314-323

[3] Gold MS, Gebhart GF. Nociceptor sensitization in pain pathogenesis. Nat Med. 2010; 16: 1248-1257.

[4] National Institute for Health and Care Excellence. Management of osteoarthritis. NICE Pathways, London, last updated: 22 January 2019. Available from: http://pathways.nice.org.uk/ pathways/osteoarthritis [accessed: April 10, 2019].

[5] World Health Organization. Cancer pain relief. Geneva, 1986. Available from: http://www.who.int/iris/handle/10665/ 43944 [accessed: April 10, 2019].

[6] Atchison JW, Herndon CM, Rusie E. NSAIDs for musculoskeletal pain management: current perspectives and novel strategies to improve safety. J Manag Care Pharm. 2013; 19(9 Suppl A): S3-S19.

[7] Verkleij SP, Luijsterburg PA, Bohnen AM, et al. NSAIDs vs acetaminophen in knee and hip osteoarthritis: a systematic review regarding heterogeneity influencing the outcomes. Osteoarthritis Cartilage 2011; 19: 921-929.

[8] Farquhar-Smith P, Gubbay A. Tramadol and acetaminophen combination for chronic non-cancer pain. Expert Opin Pharmacother. 2013 ; 14: 2297-2304.

[9] Vane JR. Inhibition of prostaglandin synthesis as a mechanism of action for the aspirin-like drugs. Nat New Biol. 1971; 231: 232 235.

[10] Ong CK, Lirk P, Tan CH, et al. An evidence-based update on nonsteroidal anti-inflammatory drugs. Clin Med Res. 2007; 5: $19-34$.
[11] Pelletier JP, Martel-Pelletier J, Rannou F, et al. Efficacy and safe ty of oral NSAIDs and analgesics in the management of osteoarthritis: evidence from real-life setting trials and surveys. Semin Arthritis Rheum. 2016 45(4 Suppl): S22-S27.

[12] Roth SH. Nonsteroidal anti-inflammatory drug gastropathy: new avenues for safety. Clin Interv Aging 2011; 6: 125-131.

[13] Jüni P, Nartey L, Reichenbach S, et al. Risk of cardiovascular events and rofecoxib: cumulative meta-analysis. Lancet 2004; 364: 2021-2029.

[14] European Medicines Agency. Assessment report for Non-Steroidal Anti-Inflammatory Drugs (NSAIDs) and cardiovascular risk. EMA/696137/2012. Available from: https://www.ema.europa.eu/en/documents/referral/assessment-report-article53-procedure-non-steroidal-anti-inflammatory-drugs-nsaidscardiovascular_en.pdf [accessed: April 17, 2019]

[15] McGettigan P, Henry D. Cardiovascular risk with non-steroidal anti-inflammatory drugs: systematic review of population-based controlled observational studies. PLoS Med. 2011; 8: el 001098.

[16] European Medicines Agency. Updated advice on use of highdose ibuprofen. EMA/325007/2015. Available from: https:// www.ema.europa.eu/en/documents/press-release/updatedadvice-use-high-dose-ibuprofen_en.pdf [accessed: April 10, 2019].

[17] Geenen R, Overman CL, Christensen R, et al. EULAR recommendations for the health professional's approach to pain management in inflammatory arthritis and osteoarthritis. Ann Rheum Dis. 2018; 77: 797-807

[18] Hochberg MC, Altman RD, April KT, et al. American College of Rheumatology 2012 recommendations for the use of nonpharmacologic and pharmacologic therapies in osteoarthritis of the hand, hip, and knee. Arthritis Care Res (Hoboken). 2012; 64: $465-474$

[19] McAlindon TE, Bannuru RR, Sullivan MC, et al. OARSI guidelines for the non-surgical management of knee osteoarthritis. Osteoarthritis Cartilage 2014; 22: 363-388.

(Sütő Gábor dr., Pécs, Pacsirta u. 1., 7624 e-mail: gabor.suto@immunologus.hu)

\section{"Carpe diem, quam minimum credula postero!" (Horatius) (Éld a napot!)}

A cikk a Creative Commons Attribution 4.0 International License (https://creativecommons.org/licenses/by/4.0/) feltételei szerint publikált Open Access közlemény, melynek szellemében a cikk bármilyen médiumban szabadon felhasználható, megosztható és újraközölhetö, feltéve, hogy az eredeti szerző és a közlés helye, illetve a CC License linkje és az esetlegesen végrehajtott módositások feltüntetésre kerülnek. (SID_1) 